\title{
THE ECONOMIC IMPACT OF INTELLECTUAL PROPERTY IN EUROPE AND HUNGARY
}

\section{A SZELLEMI TULAJDON GAZDASÁGI HATÁSA EURÓPÁBAN ÉS MAGYARORSZÁGON}

\author{
Gábor Szilágyi ${ }^{1}$ Kata Földi ${ }^{2}$ \\ ${ }^{1}$ Civil Law Department, Law Faculty, Debrecen University, Hungary \\ ${ }^{2}$ Commerce, Marketing and International Business Department, Business Administration Faculty, \\ John von Neumann University, Hungary
}

\author{
Keywords: \\ Intellectual property \\ Copyright \\ Economic impact \\ EU and Hungary \\ Kulcsszavak \\ Szellemi tulajdon \\ Szerzői jog \\ Gazdasági hatás \\ EU és Magyarország
}

\begin{abstract}
As the aim of the article, to show in the framework of theoretical research, to assess the situation of Hungarian intellectual property in the life of businesses. In our paper, we try to analyze and present this area approaching it from an economic side, which seems to be a mere legal phenomenon for an outside observer.

Összefoglalás

Az írás célja, hogy elméleti kutatás keretében megmutassa az Európai és a Magyar szellemi tulajdon helyzetét a vállalkozások életében. A tanulmányban gazdasági oldalról megközelítve igyekszünk elemezni és bemutatni ezt a külső szemlélő számára kizárólag jogi jelenségnek túnő területet.
\end{abstract}

\section{Introduction}

The basis for my choice of topic was the recognition that intellectual property protection is a key element of today's economy. Economic actors apply the instruments protected by this law day by day. Just think of a well-known brand logo as a trademark, like in case of Google, with an approximate value of 44.3 billion USD, or Vodafone, which was estimated [1] for 30.7 billion USD by Forbes in 2011. The essence of intellectual property protection is that states grant the right holder a certain degree of exclusivity. Of course, this can be interpreted as a restriction of competition. However, it is evident that these restrictions on competition are not considered illegal by the legislator because they are supported by public interest because they help economic and technological development. The roots of intellectual property protection have already been observed in antiquity in the Greek city state of Sybaris, where around 500 $\mathrm{BC}$, those chefs was granted protection for exclusive use who prepared dishes according to the regulations. [2] [3] However, the role of patent law was only a priority in the era of industrial revolutions with the introduction of capitalist production. [4] If we are thinking of the roots of

1 contact author:. Tel.: +36 (52) 512701

E-mail address: szilagyig@unideb.hu 
the trademarks representing billions of dollars that have been mentioned earlier, we see a constant function from the beginning of the area. Traditionally, trademarks answered earlier and even answers now an important question in the distinction between products (later products and services). In the ancient states, arms, pots, and other things were primarily marked with signs of their place of production, which was naturally a mean of distinction. Later, in the Middle Ages, various guild marks were placed on the products as the forerunners of collective trademarks. [5] The first known trademark in Hungary dates back to 1351 and it is the trademark of the Szentgotthárd Kaszagyár depicting a snake with a crown. [6] In Hungary, the Hungarian Intellectual Property Office (hereinafter referred to as HIPO) is the national administrative authority that has competence in proceedings concerning intellectual property. HIPO also carries out significant scientific and scientific developer activities, including the biennial publication of the Industrial Property and Copyright Review.

\section{The role of innovation}

Entrepreneurs have always been seen as free spirits, heroic figures that defy existing way of thinking. They are "creative destruction" force that is always trying to find better way through innovation. As we can see creativity has always been closely connected to innovation. Innovation is the process through which the entrepreneur converts market opportunities into workable, profitable, and marketable ideas. It is an application of something creative that has a significant impact on an organization, industry or society. Entrepreneurship is the continuing generation of Innovation in response to perceived opportunities in the business environment. In this approach, entrepreneurship is therefore concerned with newness: new ideas, products, services or combinations of resources aimed at meeting the needs of consumers more efficiently. Innovation is important not just in entrepreneurship. As individuals, we are innovators by adapting well to our needs and create our own solutions. Entrepreneurs are the same. The innovation in entrepreneurship helped the country by changing with the times and producing new products and service from ones that already exists. Innovation is "value" -the creation of value adding value to customer's satisfaction - "delighting" the customers. And, being innovative has helped us become successful in all our endeavors. [7]

The subject of the investigations is closely related to the manifestation of the extent and mode of domestic innovation. Based on my assumption, innovation is one of the keys to exponential or linear growth of business growth. This is evidenced by the Solow-Swan model [8], which defines three basic production factors for economic growth; namely capital (K), labour (L), and innovation/knowledge/technological development/entrepreneurship (A). Where the latter (A) influences the effectiveness of the first two factors (L, K).

The cluster below (Figure 1) shows the location of European countries and their clustering on the basis of the Roland Berger index. It can be said of Hungary that it was clustered in the "Traditional Industry" cluster. Developing technical knowledge is not enough for further development and increase of competitiveness; it is also necessary to develop the innovation capability, which is part of the innovative business model among others [9].

On the basis of the analysis of clusters (Figure 1), it can be observed that Hungary was placed in the "traditional industry" cluster, similar to the V4 countries (except Poland). The share of industrial production in GDP is high, but the Roland-Berger index is low. Thus, it can be said that Hungary's economic performance is highly dependent on industry, but it is not really prepared for digital transformation compared to other European competitors. The role of intellectual property in the economy is closely linked to innovation. The European Union Intellectual Property Office (hereinafter: EUIPO) examined the contribution of intellectual property-intensive sectors to gross domestic product (Figure 2). An important observation here is that the intellectual property-intensive sectors account for a total of $42.3 \%$ of all EU GDP. 


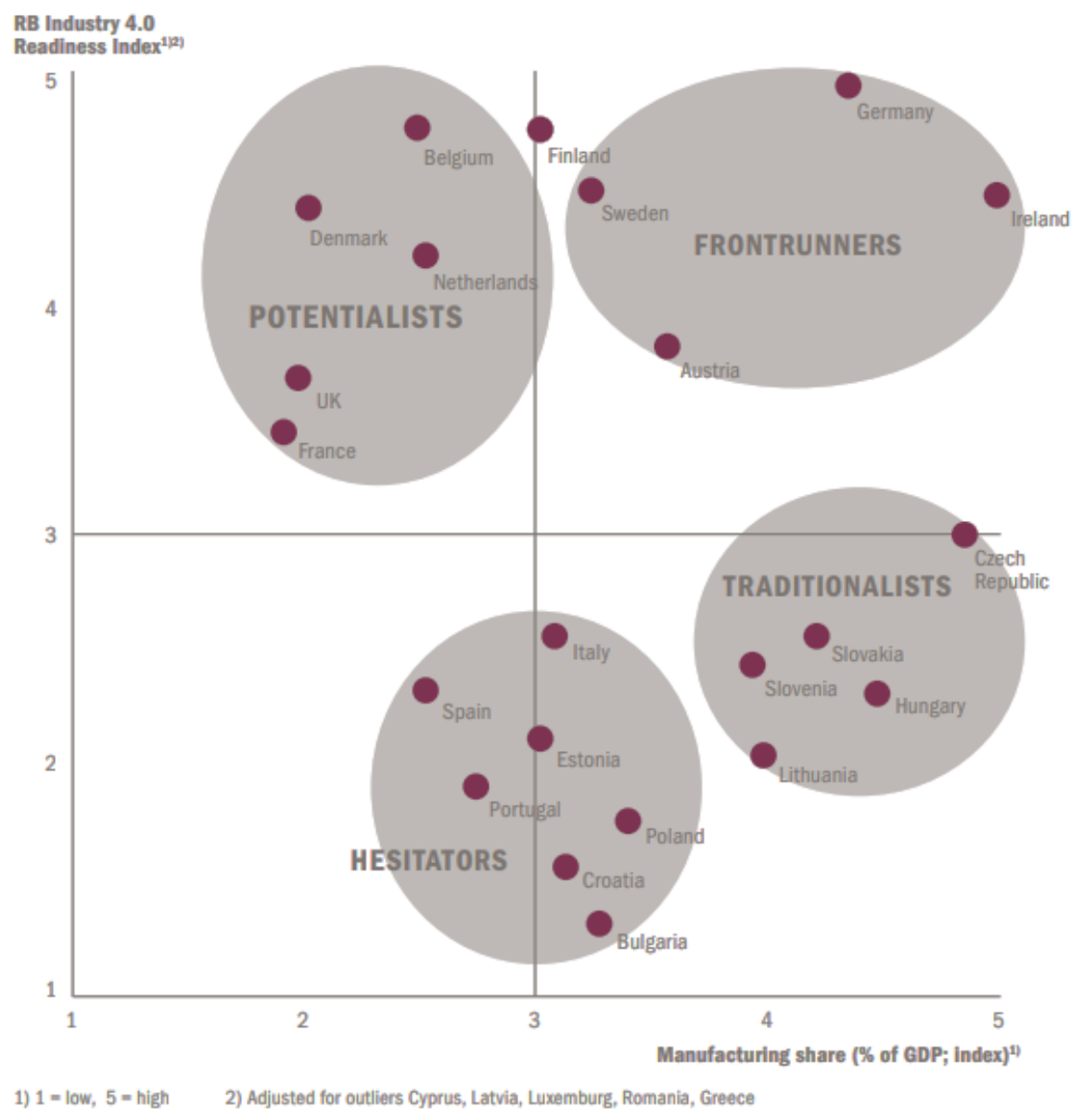

Figure 1 Clusters in Europe based on Industry 4.o Readiness Index [10]

The table (Table 1) shows the contribution of different forms of protection of intellectual property rights to total EU GDP [million euros] and the percentage share of each sector within total GDP. It should be emphasized that trademark-intensive industries contribute $35.9 \%$ of total EU GDP, while the design-intensive contribute $13.4 \%$, patent-intensive $15.2 \%$, and copyright-intensive sectors contribute $6.8 \%$. Intellectual property-intensive sectors, in total, represent $42.3 \%$ of the total EU gross domestic product, which shows well the importance of the area.

Table 1 Contribution of IP Intensive Industries to GDP (2011-2013 average) [11]

\begin{tabular}{|l|l|l|}
\hline \multicolumn{1}{|c|}{ IPR-intensive industries } & \multicolumn{1}{c|}{ Value Added/GDP (€ million) } & \multicolumn{1}{c|}{ Share of total EU GDP } \\
\hline Trade-mark-intensive & $4,812,310$ & $35.9 \%$ \\
\hline Design-intensive & $1,788,811$ & $13.4 \%$ \\
\hline Patent-intensive & $2,035,478$ & $15.2 \%$ \\
\hline Copyright-intensive & 914,612 & $6.8 \%$ \\
\hline GI-intensive & 18,109 & $0.1 \%$ \\
\hline PVR-intensive & 51,710 & $0.4 \%$ \\
\hline All IPR-intensive & $5,664,168$ & $42.3 \%$ \\
\hline Total EU GDP & $13,387,988$ & \\
\hline
\end{tabular}

Note: due to overlapping use of IP rights, the sum of the figures for the individual IPR exceeds the total figure for IPR-intensive industries. 


\section{Economic role of intellectual property}

Intellectual property rights (IPRs) have attracted increasing attention both in academic circles as well as in public policy debates over the past decades. This has gone hand-in-hand with their increasing use, particularly (but not only) patents, reforms in the national and international legal frameworks that have resulted in the strengthening of IPRs and the fast growth of sectors in which knowledge, innovation and appropriability play a key role (e.g. biotechnology, information and communication technologies and the cultural industries). Intense debates among researchers have taken place on a wide range of issues, including the reasons for the growing use of IPRs; the impact of the strengthening of IPRs on innovation; the role of IPRs in developing countries; whether there is a need for international harmonization of the laws regulating the matter and the consequences of IPR legislative reforms on poor communities in areas such as health or traditional knowledge. [12].

We will begin the discussion of the topic in detail, and we would like to make an attempt to categorize briefly the legal institutions examined, the mass of which appears in the business life. They can have a significant economic role, as I will try to explore it later.

Our lives are surrounded by intellectual creations, wherever we look, we have a great chance of meeting them. Coca-Cola Company, Walt Disney Productions, General Electric, or even Chanel, have at least one common feature. Namely, each company created and implemented a successful intellectual property strategy that led them through critical first steps and they became the world's leading companies within their markets. [13] To illustrate this, we quote Walt Disney's words: "I hope we never lose sight of one thing, that it was all started by a mouse", and indeed the whole story started with a little drawn mouse figure, the intellectual creation of the author, Walt Disney. Subsequently, there were a number of factors that clearly led to world success, but still, an intellectual creation was the foundation of it. If we would like to classify the legal institutions covered by intellectual property protection, the following figure (Figure 2) is presented to us.

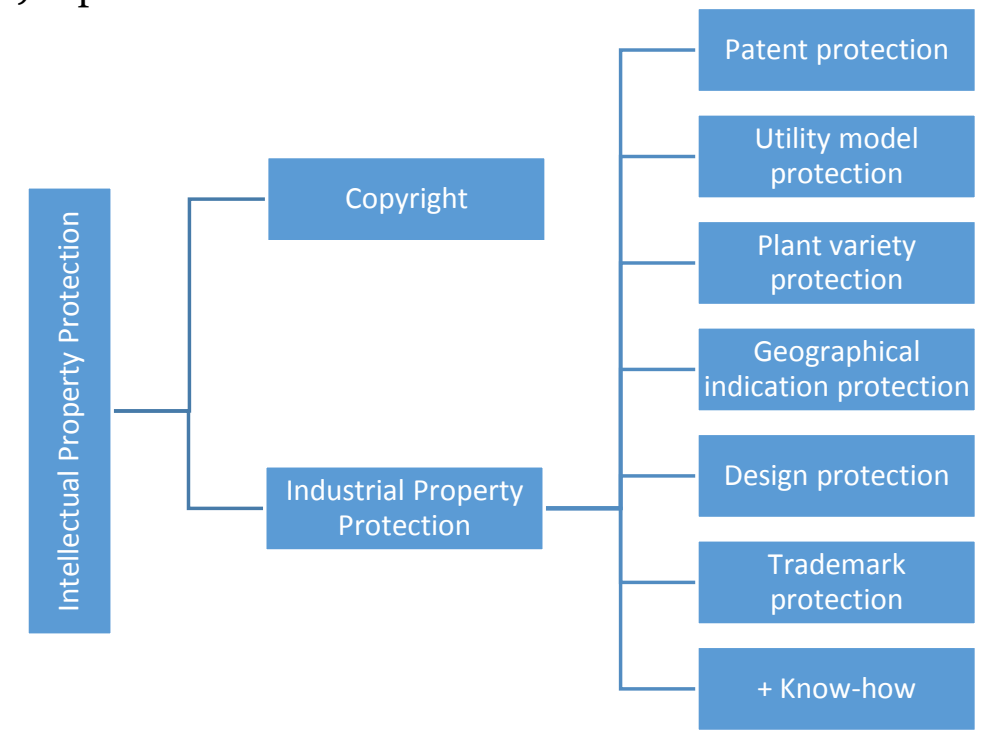

Figure 2 Systems of Intellectual Property Rights

As can be seen in the figure (Figure 2), intellectual property protection is divided into two large groups of copyright and industrial property rights.

\section{Copyright}

Copyright encompasses its narrower content, i.e. the protection of literary, scientific and artistic works, and the so-called related rights, which include sui generis rights related to databases and neighbouring rights. [14] The first source work on the economic effects of copyright was published in 1934 [15], and there the author studied pervasively the economic relations of this area of law. 


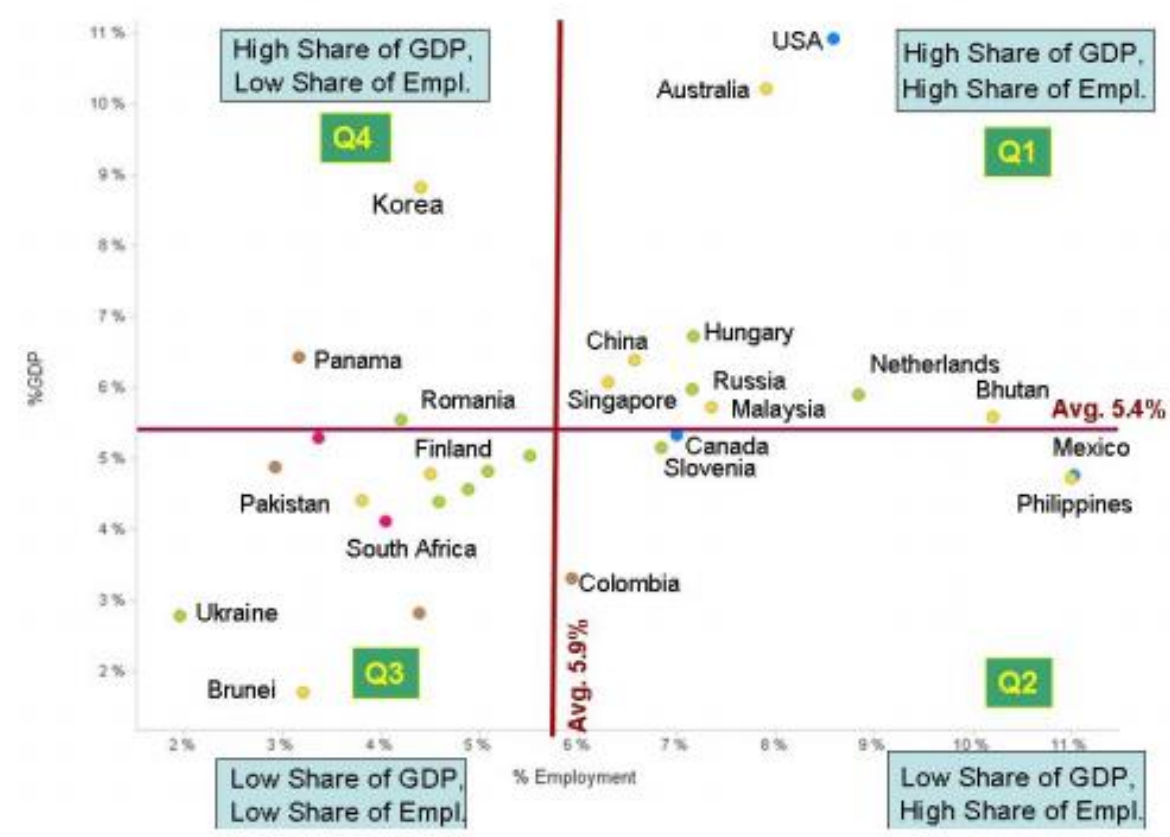

Figure 3 The contribution of copyright to GDP and the cluster of countries based on employment [16]

As shown in the cluster above (Figure 3). The majority of countries - including Hungary - were classified into Cluster Q1, where the contribution to GDP and employment is high. The clustering data were based on national studies. The study also discusses the factors that determine the underlying values of the study. Examples include the positions of the copyright industries on the domestic and global markets, national policies supporting the industry, monetary value associated with creative products, national traditions, and cultural characteristics.

\section{Patent protection}

Patent protection is perhaps the most important element of industrial property protection, and the truly famous inventions are also connected to this (such as the ballpoint pen invented by László Bíró, or by János Neumann, and many other inventions of great inventors). Patent activity is also reflected in the rather interesting statement when the number of domestic inventors is counted as hundreds of billions of national incomes. The number of inventors thus obtained was 9,676 in South Korea, 5,871 in Japan, 4,657 in China, 2,101 in Germany, and 1,825 in Switzerland in 2014. [17]. Patent activity in the world's most advanced countries developed as follows in 2014: China 928.177, USA 578.802, Japan 325,969, South Korea 210,292, and the European Patent Office where 152,662 patent applications have been made.

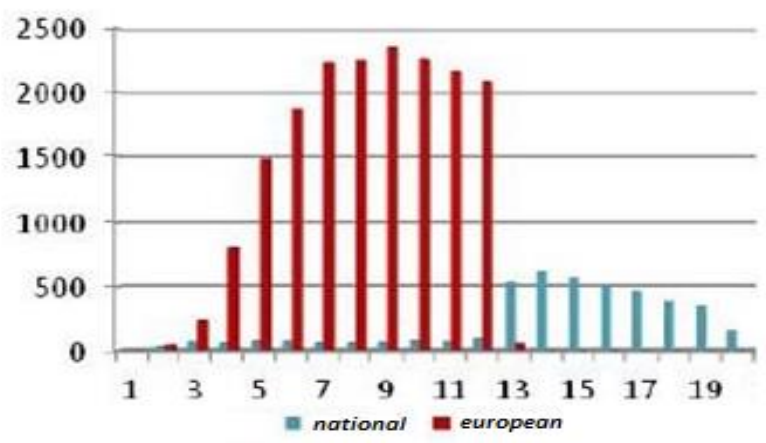

Figure 4 Age structure diagram of patents in force in Hungary, 2015 [18] 
The graph (Figure 4) shows that the number of national patents has fallen significantly with the possibility of a European patent application, but European patents have survived in significantly greater numbers after several years, than in case of national patent protection. On the basis of the data it can be stated that nearly three thousand five hundred national patents have been in force in Hungary for at least 13 years.

\section{Design protection}

Comparing the design protection to the patent, we can see a similar but slightly different construction. While a patent protects a technical solution, the design right protects the exterior design. For example, while the iPhone is protected by a patent as a technical solution (US $7,479,949 \mathrm{~B} 2$ ), its design and form are protected by a design protection (US D618,677S). As can be seen from the above presentation, the most prominent role of this form of protection is in the field of entertainment electronics, home appliances, furniture and clothing. [17]. Innovation here is a uniquely designed product that draws the customer's attention and increases sales volume or purchase price. The European Commission has highlighted design as a "marketing tool", and it drew attention to the fact that in many cases it is the appearance that determines the success of a product - not just technical content - on the market. As a result, companies that invest capital in design can become significantly profitable. [17] Based on industry estimates, market failure in case of a new product can be attributed to inadequate or almost completely missing design in $85 \%$ of cases. [18] In the European Union, $42.3 \%$ of the GDP (added value) of the economy between 2011 and 2013, and 27.8\% of employment, derived from intensive sectors of intellectual property. The value added per employee is thus higher than in other economic areas, and this is compensated by employers in wages. The average weekly wage is $€ 776$ in intense intellectual property sectors, while in other industries it is only $€ 530$. [10] In the world, most design protection applications have been made based on 2014 data as follows: China 964,555, Community Trademark Office 98,273², South Korea 68.444, Germany 61.054, and Turkey 48,799. [15] In a thought I find it important to shed light on the distinction between design and general design based on the European Design Council's "Design for Growth and Prosperity" report, which states that design has emotional, social, and environmental implications while general design is a broader concept. [17].

\section{Acknowledgement}

This research is supported by EFOP-3.6.1-16-2016-00006 "The development and enhancement of the research potential at John von Neumann University" project. The Project is supported by the Hungarian Government and co-financed by the European Social Fund.

\section{Bibliographical References}

[1] Stonefield, S. (2011): The 10 Most Valuable Trademarks, Forbes Media LLC, 15. Jun. 2011. [Online]. Available: https://www.forbes.com/sites/seanstonefield/2011/06/15/the-10-most-valuabletrademarks/\#133834c236b8. [Accessed: 28-Sept-2018].

[2] Smith, F. E. (1960): Serendipity and Patentable Invention. In: Journal of the Patent Office Society, 42 6) pp. 431.

[3] Malackowski, J. E. (2011): Next Big Thing in Monetizing IP: A Natural Progression to Exchange-Traded Units. Landslide, 3(5) pp. 32.

[4] Papp, L. (2013): Mérföldkövek a szabadalmi jog egyetemes fejlődésében a XIX. század. In: Iparjogvédelmi és Szerzői Jogi Szemle, 118 (5). pp. 42-59.

[5] Csécsy, G. (2001): Védjegyjog és piacgazdaság, Novotni Alapítvány a Magánjog Fejlesztéséért, Miskolc

[6] Vida, S. (1982): A védjegy és Vállalat. Közgazdasági és Jogi Könyvkiadó, Budapest

[7] Kheni, S. (2017): Role of Innovation. In: Entrepreneurship Development Aarmss International Journal Of Management And Social Sciences Research, 3 (2) [Online]. Available: http://www.aarmssjournals.com/wpcontent/uploads/2017/07/1-5_ijmssr_vol3_2_jun17.pdf [Accessed: 20-Jan-2019].

[8] Solow, R. M. (1956): A Contribution to the Theory of Economic Growth. In: The Quarterly Journal of Economics, 70 (1)pp. 65-94.

[9] Pongrácz, F. - Nick, G. (2017): Innováció - a fenntartható növekedés kulcsa Magyarországon. In: Közgazdasági szemle, 64. pp. 723-737.

\footnotetext{
2 Based on WIPO database
} 
[10] Berger, R. (2014): Industry 4.o. The new industrial revolution. How Europe will succeed, Roland Berger Strategy Consultants, Munich

[11] Wajsman, N. - Ménière, Y. - Kazimierczak, M. - Arias Burgos, C. - Dvořáková, A. - Rudyk, I. (2016): Intellectual property rights intensive industries and economic performance in the European Union. European Union Intellectual Property Office, Alicante

[12] López, A. - Arora, A. - Watt, R. - Bramley, C. - Biénabe, E. - Kirsten, J. - Cockburn, I. M. - Montobbio, F. (2009:) Innovation and Appropriability. Empirical Evidence and Research Agenda in the Economics of Intellectual Property [Online]. Available: https://www.wipo.int/edocs/pubdocs/en/economics/1012/ wipo pub 1012.pdf [Accessed: 14-Feb-2019]

[13] Arena, C. M. - Carreras, E. M. (2018): Business of Intellectual Property, Oxford University Press, New York

[14] Posteinerné Toldi, M. (Ed.) (2012): Iparjogvédelem, Szellemi Tulajdon Nemzeti Hivatala, Budapest

[15] Plant, A. (1934): The Economic Aspects of Copyright in Books. In: Economica - New Series, 1 (2) pp. 167-195.

[16] WIPO (2015): Guide on Surveying the Economic Contribution of the Copyright-Based Industries. World Intellectual Property Organization, Geneva

[17] Tattay, L. (2016): Versenyképesség és szellemi alkotások az Európai Unióban. Wolters Kluwer, Budapest

[18] Jedlik-terv Nemzeti Stratégia a Szellemi Tulajdon Védelmére (2013): Magyarország Kormánya, Budapest 
(iii) 